\title{
Seasonal and spatial variability in snow chemistry at Eclipse Icefield, Yukon, Canada
}

\author{
Kaplan YALCIN, ${ }^{1,2^{*}}$ Cameron P. WAKE, ${ }^{1}$ Shichang KANG, ${ }^{3}$ Karl J. KREUTZ, \\ Sallie I. WHITLOW ${ }^{1}$ \\ ${ }^{1}$ Climate Change Research Center, Institute for the Study of Earth, Oceans, and Space, University of New Hampshire, \\ Durham, NH 03824, USA \\ ${ }^{2}$ Department of Geosciences, Idaho State University, Pocatello, ID 83209, USA \\ E-mail: yalckapl@isu.edu \\ ${ }^{3}$ Institute of Tibetan Plateau Research, Chinese Academy of Sciences, 18 Shuangqing Road, Haidian District, \\ Beijing 100085, China \\ ${ }^{4}$ Climate Change Institute and Department of Earth Sciences, University of Maine, 303 Bryand Global Sciences Center, \\ Orono, ME 04469-5790, USA
}

\begin{abstract}
Samples collected from four snow pits at Eclipse Icefield, Yukon, Canada, were analyzed for stable isotopes and major ions to assess seasonal and spatial variability in snow chemistry. Accumulation since the end of the 2001 summer season over the $0.1 \mathrm{~km}^{2}$ area sampled ranges from 0.77 to $1.16 \mathrm{~m}$ w.e. Snow-pit stratigraphy and chemical records demonstrate that the low accumulation at pit 3 is due to an under-representation of winter snow accumulation at that site. For all major-ion species, chemical concentrations are independent of snow accumulation rate. Seasonal variations are evident in the majorion records and can be divided between sea-salt species $\left(\mathrm{Na}+, \mathrm{Cl}^{-}\right)$that peak in late fall to winter, and dust $\left(\mathrm{Ca}^{2+}, \mathrm{Mg}^{2+}, \mathrm{K}^{+}\right)$and other species $\left(\mathrm{NH}_{4}{ }^{+}, \mathrm{NO}_{3}{ }^{-}, \mathrm{SO}_{4}{ }^{2-}, \mathrm{C}_{2} \mathrm{O}_{2}{ }^{2-}\right)$ that peak in late spring to summer. The signal common to all four snow pits identified by empirical orthogonal function analysis ranges from $49 \%$ of the total variance for $\mathrm{Na}^{+}$and $\mathrm{Cl}^{-}$to as high as $80 \%$ of the total variance for $\mathrm{SO}_{4}{ }^{2-}$. There is greater spatial variability in species associated with coarse-mode particles $\left(\mathrm{Na}^{+}, \mathrm{Cl}^{-}, \mathrm{Ca}^{2+}, \mathrm{Mg}^{2+}\right)$ than in species present mainly in accumulation-mode aerosols $\left(\mathrm{SO}_{4}{ }^{2-}, \mathrm{NH}_{4}{ }^{+}\right)$or in the gas phase $\left(\mathrm{NO}_{3}{ }^{-}\right)$.
\end{abstract}

\section{INTRODUCTION}

Proxy records developed through physical and chemical analyses of ice cores arguably provide the highest-resolution and most direct view of Earth's paleo-atmosphere over timescales ranging from decades to hundreds of thousands of years (e.g. Legrand and Mayewski, 1997). Ice cores spanning the last 100-1000 years have been recovered from Eclipse Icefield $\left(60.51^{\circ} \mathrm{N}, 139.47^{\circ} \mathrm{W} ; 3017 \mathrm{ma.s.I}\right.$.) in the St Elias Mountains, Yukon, Canada (Yalcin and Wake, 2001; Yalcin and others, 2006). The St Elias Mountains, bordering the North Pacific Ocean, are at the end of the North Pacific storm track and act as a climatic divide separating maritime and polar regimes (Taylor-Barge, 1969). Although mean annual temperature at the Eclipse site as estimated from borehole temperature at $20 \mathrm{~m}$ depth is around $-8^{\circ} \mathrm{C}$, limited surface melting does occur during summer (averaging $5 \%$ of the net accumulation by weight per year). Meltwater percolation does not extend to previous annual layers due to the high snow accumulation rate (averaging $1.30 \mathrm{~m}$ w.e. for the period 2002-1963), and therefore does not significantly alter glaciochemical signals. The high accumulation and limited surface melting makes Eclipse Icefield suitable for developing high-resolution records of natural and anthropogenic environmental change in the northwest North American Arctic over the last few centuries. The Eclipse ice cores have yielded insights into anthropogenic sulfate and nitrate trends in this part of the Arctic (Yalcin and Wake, 2001), relationships between ice-core proxy records

*Present address: Department of Geosciences, Oregon State University, Corvallis, OR 97333, USA. and meteorological variables (Wake and others, 2002), North Pacific volcanism (Yalcin and others, 2003), and variations in regional forest fire activity due to not only natural climate variability but also anthropogenic influences (Yalcin and others, 2006).

In order to fully utilize the glaciochemical records available from Eclipse Icefield, a robust understanding of the controls on snow chemical composition, seasonal input timing and spatial variability in snow chemistry at the Eclipse site is required. Snow-pit sampling provides a useful tool to investigate these properties (e.g. Mayewski and others, 1990; Kreutz and others, 1999; Wake and others, 2004). Comparison of snowpack chemistry at Summit, Greenland, and the South Pole demonstrates differences in both relative importance and seasonal input timing of crustal and sea-salt species (Whitlow and others, 1992). Dust species peak in boreal spring at Summit but in austral fall at the South Pole due to differences in timing of long-range transport from continental source areas. Furthermore, sea salt is a much more important source of $\mathrm{Mg}^{2+}$ at the South Pole due to much lower dust concentrations. Snow-pit studies assessing the spatial representativeness of Summit ice-core records have reported greater spatial variability in snow chemistry for species present as coarse-mode particles than for species found in the accumulation mode or gas phase (e.g. Dibb and Jaffrezo, 1997). Snow-pit studies can also help improve ice-core dating via a multi-parameter approach identifying seasonal variations in glaciochemical species (e.g. Kreutz and others, 1999).

Identifying any potential dependence of chemical concentration and flux on snow accumulation can also aid the interpretation of ice-core data (Yang and others, 1996; 
Kreutz and others, 2000). For example, if chemical concentration is found to be independent of snow accumulation, concentration changes can be interpreted in terms of changes in source strength and/or atmospheric circulation. On the other hand, if chemical concentration is dependent on snow accumulation, changes in accumulation rate over different timescales could obscure changes in concentration due to source strength or transport mechanisms. Ice-core data from Greenland, Mount Logan, Yukon, and the Himalaya demonstrate that major-ion concentrations are independent of snow accumulation over accumulation rates ranging from 0.23 to $0.60 \mathrm{~m}$ w.e. (Yang and others, 1995). However, nitrate flux was found to have a strong linear relationship to accumulation, suggesting the atmospheric supply of nitrate is sufficiently large to remain undepleted by precipitation at these accumulation rates. The $1.30 \mathrm{~m}$ w.e. accumulation rate at Eclipse Icefield offers the opportunity to investigate the relationship between chemical concentration, chemical flux and accumulation rate with a highaccumulation-rate site.

In this paper, we present the results of a snow-pit survey for stable isotopes and major ions at Eclipse Icefield during the 2002 field season. Since our snow pits cover only a single year's accumulation, we expand our discussion to include ice-core data from Eclipse to overcome this limitation. The results allow us to characterize the chemistry of recent snowfall at Eclipse, define the relative contributions of seasalt vs non-sea-salt sources, investigate the dependence of chemical species concentration and flux on snow accumulation rate, identify the seasonal input timing and assess the spatial variability in glaciochemical signals at Eclipse.

\section{METHODS}

As part of ice-core drilling efforts at Eclipse Icefield during May and June 2002, four snow pits were sampled for major ions and stable isotopes. The $4 \mathrm{~m}$ snow pits were located approximately $100 \mathrm{~m}$ to the north, west, south and east of the 2002 drilling site, respectively (Fig. 1). Stringent sampling protocols were used to ensure samples were contaminationfree at the $\mathrm{ng} \mathrm{g}^{-1}$ level. All sampling equipment and sample containers were pre-cleaned with Milli-Q water at the University of New Hampshire by rinsing three times, soaking for at least 24 hours, rinsing three times, and drying in a laminar-flow bench in a clean room. Snow pits were sampled continuously at $5 \mathrm{~cm}$ resolution by personnel wearing nonparticulating suits, plastic gloves and dripless face masks. A pre-cleaned stainless-steel sampling tool was used to pack samples directly into pre-cleaned $60 \mathrm{~mL}$ polypropylene containers. A total of 320 snow-pit samples were collected for major-ion and stable-isotope analyses. Density measurements were made every $10 \mathrm{~cm}$. A stratigraphic description, including the location and thickness of ice layers from surface melting during summer, was made for each pit (Fig. 2).

Samples were transported frozen to the University of New Hampshire where they were melted and $5 \mathrm{~mL}$ aliquots taken for major-ion and stable-isotope analysis. Samples were analyzed for major ions $\left(\mathrm{Na}^{+}, \mathrm{NH}_{4}{ }^{+}, \mathrm{K}^{+}, \mathrm{Mg}^{2+}, \mathrm{Ca}^{2+}, \mathrm{Cl}^{-}\right.$, $\mathrm{NO}_{3}{ }^{-}, \mathrm{SO}_{4}{ }^{2-}, \mathrm{C}_{2} \mathrm{O}_{4}{ }^{2-}$ ) via ion chromatography using a $0.5 \mathrm{~mL}$ sample loop in a dedicated laboratory at the Climate Change Research Center. The cation system used a CS12A column with CSRS-ultra suppressor in auto-suppression recycle mode with $20 \mathrm{mM}$ methanesulfonic acid (MSA) eluent. The anion system used an AS11 column with an ASRS-ultra suppressor

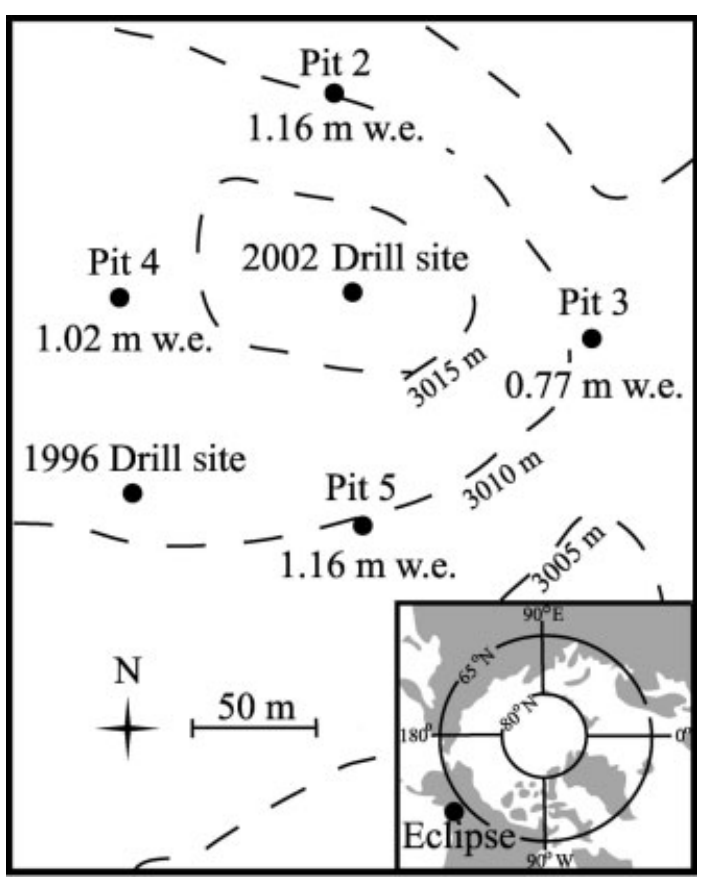

Fig. 1. Location map for 2002 Eclipse Icefield snow pits in relation to the 2002 drill site. The accumulation in $\mathrm{m}$ w.e. at each snow pit since the end of the 2001 melt season is indicated. Surface topography indicated by $5 \mathrm{~m}$ contours.

in auto-suppression recycle mode with $6 \mathrm{mM} \mathrm{NaOH}$ eluent. Analytical precision was monitored by analyzing $10 \%$ of the samples in duplicate and found to be $11 \%$ for $\mathrm{K}^{+}, 10 \%$ for $\mathrm{NH}_{4}{ }^{+}, 7 \%$ for $\mathrm{Na}^{+}$, and $<5 \%$ for all other species. Detection limits were $<2 \mathrm{ngg}^{-1}$ for $\mathrm{NO}_{3}{ }^{-}, \mathrm{SO}_{4}{ }^{2-}$ and $\mathrm{C}_{2} \mathrm{O}_{4}{ }^{2-}$ and $<1 \mathrm{ng} \mathrm{g}^{-1}$ for all other species. Stable isotopes $\left(\delta^{18} \mathrm{O}\right)$ were analyzed at the University of Maine Stable Isotope Laboratory with a Multiprep $\mathrm{CO}_{2}$ equilibration system coupled to a VG SIRA mass spectrometer (precision $\pm 0.05 \%$ ). Concentrations of $\mathrm{K}^{+}, \mathrm{Mg}^{2+}, \mathrm{Ca}^{2+}, \mathrm{Cl}^{-}$and $\mathrm{SO}_{4}{ }^{2-}$ were partitioned into sea-salt and non-sea-salt fractions on a per sample basis using $\mathrm{Na}^{+}$as the sea-salt indicator and the micro-equivalent ratios of $\mathrm{Na}^{+}$to other ions in sea water, assuming no fractionation of the sea-salt aerosol during transport and deposition (Keene and others, 1986).

Snow-pit stratigraphic properties and seasonal variations in $\delta^{18} \mathrm{O}$ were used to date the snow pits (Fig. 2). Two high$\mathrm{Ca}^{2+}$ and $-\mathrm{Mg}^{2+}$ dust events in the spring and fall of 2001 provided additional timelines. The spring $2001 \mathrm{Ca}^{2+}$ and $\mathrm{Mg}^{2+}$ event could be the local signature of the April 2001 Asian dust plume that traveled across North America (De Bell and others, 2004; Zdanowicz and others, 2004). Placing the four snow pits on a common depth-age scale allows us to investigate the variability in glaciochemical signals between the four snow pits without variation in accumulation rates influencing our results.

This step was necessary in our analysis because available data indicate that a gradient in accumulation exists across the ice field. Using the location of ice layers and the $\delta^{18} \mathrm{O}$ records as the most reliable indicator of summer vs winter snowfall, we found that accumulation since the end of the 2001 melt season ranged from $0.77 \mathrm{mw}$.e. at pit 3 to $1.02 \mathrm{~m}$ w.e. at pit 4 and $1.16 \mathrm{~m}$ w.e. at pits 2 and 5 (Fig. 1). Inspection of snow-pit stratigraphy and oxygen isotope records (Fig. 2) demonstrates the low accumulation at pit 3 

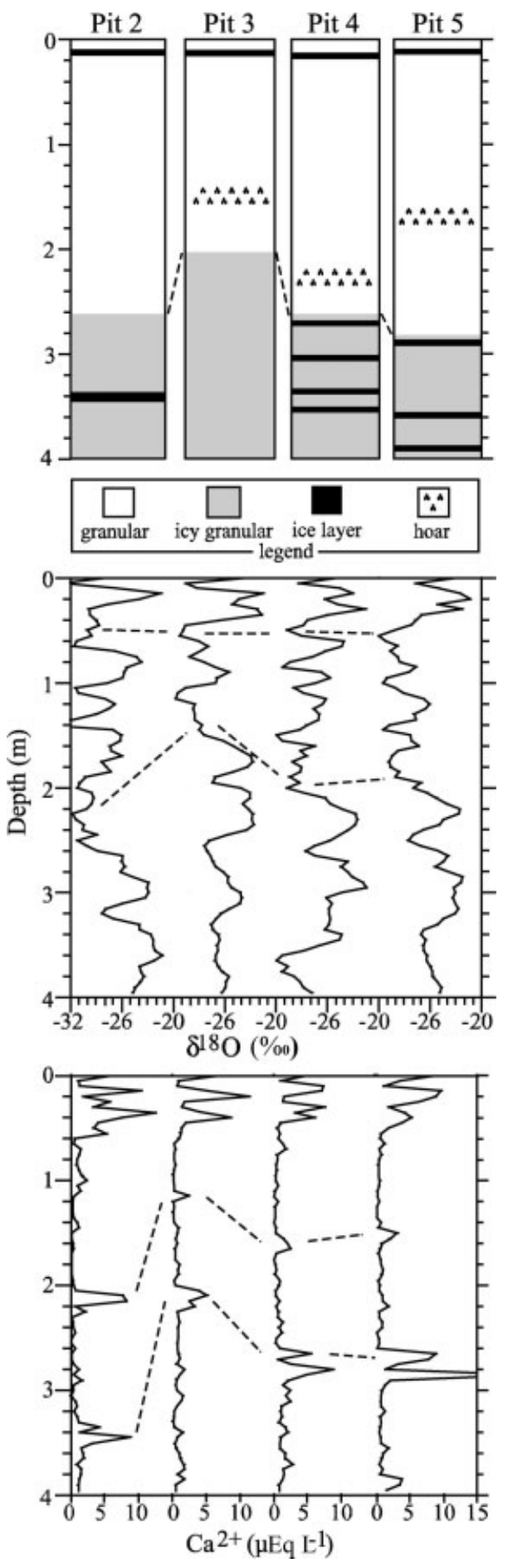

Fig. 2. Key stratigraphic and glaciochemical features used to date the snow pits. Dashed lines indicate tie lines provided by events believed to be synchronous. Note the lower winter snow accumulation in pit 3 as indicated by snow-pit stratigraphy and $\delta^{18} \mathrm{O}$ records. is due to under-representation of winter snowfall at this site. The mountain slope to the east of pit 3 could produce a funneling effect focusing wind energy along the east side of the ice field, leading to enhanced wind erosion and removal of low-density winter snow at pit 3. Other snow-pit surveys have also reported similar variability in snow accumulation rates over local areas (e.g. Goto-Azuma and others, 1997; Kreutz and others, 1999), and found wind scour and removal particularly important for controlling the accumulation distribution of winter snow (Fisher and others, 1983). The Eclipse ice cores suggest this gradient has remained stable over the last $>40$ years because average annual accumulation since 1963 at the $1996 \mathrm{~m}$ drill site (1.38 mw.e.; Yalcin and Wake, 2001) is $7 \%$ more than at the 2002 drill site $(1.30 \mathrm{~m}$ w.e. $)$. The 1996 drill site is $100 \mathrm{~m}$ southwest of the 2002 drill site, and therefore is further removed from the wind-scour effect of the mountain slope bordering the east side of the ice field.

Since our snow pits cover only one accumulation year, this places an inherent limitation on our results. To investigate the dependence of concentration on snow accumulation, a multi-year dataset is required. We use the 100 year record of snow chemistry at Eclipse Icefield provided by the Eclipse 1996 ice core to investigate the relationships between concentration and accumulation. Details of the analysis and dating of this core are provided elsewhere (Yalcin and Wake, 2001; Wake and others, 2002; Yalcin and others, 2003). We also use Eclipse ice-core data to summarize seasonal variations in snow chemistry because our snow-pit data record the seasonality for 1 year only.

\section{RESULTS AND DISCUSSION \\ Snow chemical composition}

The snow-pit chemical profiles are plotted vs depth in Figure 3. The Eclipse snow-pit data are summarized on a micro-equivalent per liter $\left(\mu \mathrm{EqL}^{-1}\right)$ basis in the box plots shown in Figure 4, with summary statistics provided in Table 1. Calcium is the predominant cation in our samples, followed by $\mathrm{Mg}^{2+}, \mathrm{Na}^{+}, \mathrm{NH}_{4}{ }^{+}$and $\mathrm{K}^{+}$, the last of which is present at very low concentrations. Sulfate is the predominant anion, followed by $\mathrm{NO}_{3}{ }^{-}$and $\mathrm{Cl}^{-}$. On a per sample basis, $\mathrm{Ca}^{2+}$ concentrations are the highest of the cations in $82 \%$ of the samples, followed by $\mathrm{Na}^{+}(15 \%)$ and $\mathrm{NH}_{4}{ }^{+}(3 \%)$. Sulfate is the most concentrated anion in $63 \%$ of our samples, followed by $\mathrm{NO}_{3}{ }^{-}(21 \%)$ and $\mathrm{Cl}^{-}(16 \%)$.

The completeness of major-ion analysis can be checked by the charge balance (ratio of major cation equivalents to major anion equivalents). A value not significantly different from 1 indicates an excellent balance between measured cations and anions and suggests all major ions present have

Table 1. Summary statistics of snow-pit chemical composition

\begin{tabular}{|c|c|c|c|c|c|c|c|c|c|c|}
\hline & $\delta^{18} \mathrm{O}$ & $\mathrm{Na}^{+}$ & $\mathrm{NH}_{4}{ }^{+}$ & $\mathrm{K}^{+}$ & $\mathrm{Mg}^{2+}$ & $\mathrm{Ca}^{2+}$ & $\mathrm{Cl}^{-}$ & $\mathrm{NO}_{3}{ }^{-}$ & $\mathrm{SO}_{4}{ }^{2-}$ & $\Delta C^{*}$ \\
\hline Mean & -26.80 & 0.39 & 0.34 & 0.06 & 0.52 & 1.63 & 0.49 & 0.67 & 0.93 & 0.79 \\
\hline Median & -26.82 & 0.25 & 0.21 & 0.04 & 0.31 & 0.81 & 0.36 & 0.45 & 0.64 & 0.22 \\
\hline Std dev. & 2.77 & 0.40 & 0.33 & 0.07 & 0.62 & 2.47 & 0.41 & 0.61 & 0.92 & 2.30 \\
\hline Maximum & -21.22 & 2.93 & 2.05 & 0.51 & 4.72 & 23.74 & 3.05 & 4.38 & 5.90 & 21.44 \\
\hline Minimum & -34.32 & 0.01 & 0.03 & 0.00 & 0.03 & 0.00 & 0.05 & 0.08 & 0.12 & -3.54 \\
\hline
\end{tabular}

* Sum of measured cations minus sum of measured anions. 

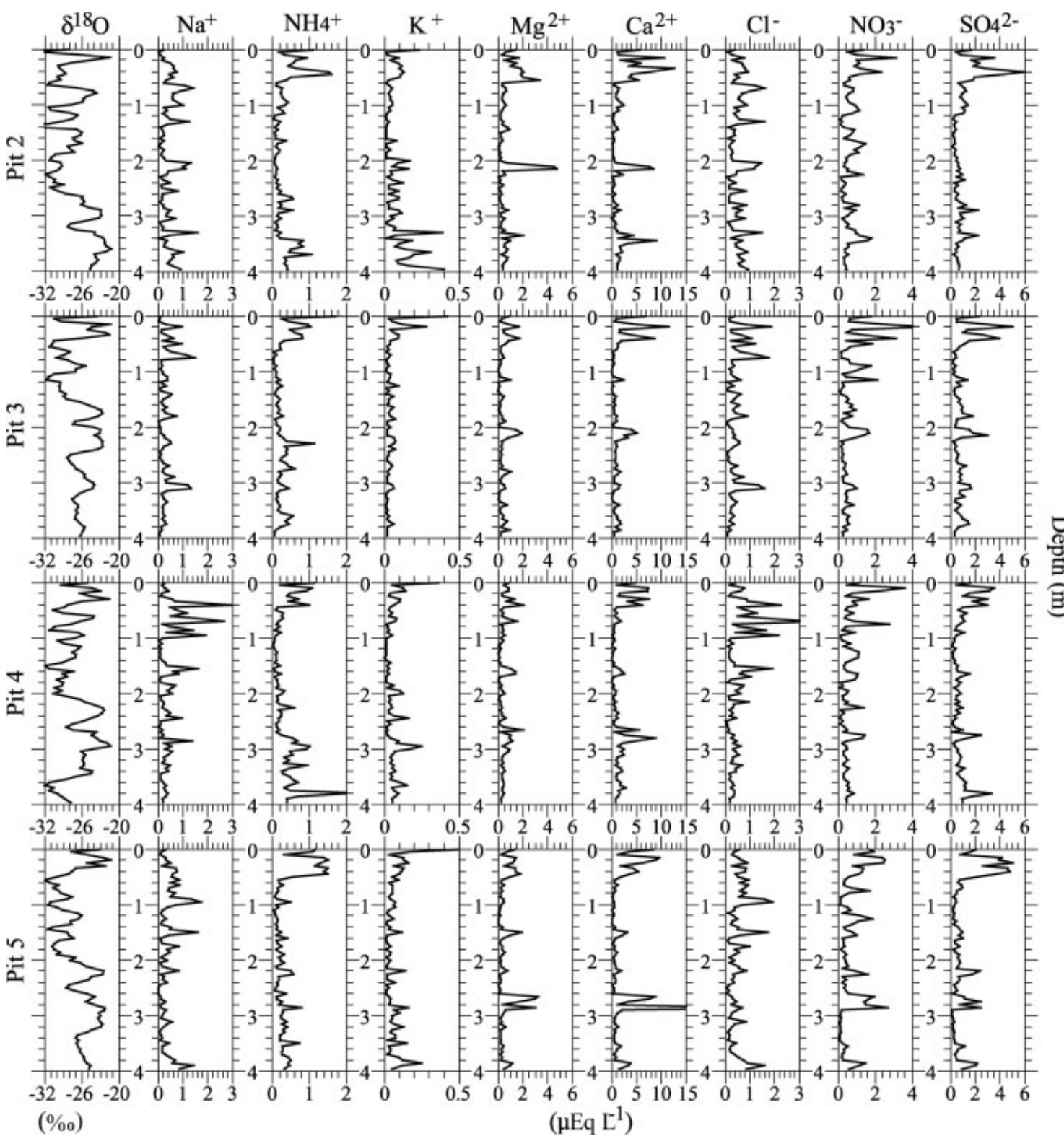

Fig. 3. Snow-pit profiles of $\delta^{18} \mathrm{O}, \mathrm{Na}^{+}, \mathrm{NH}_{4}{ }^{+}, \mathrm{K}^{+}, \mathrm{Mg}^{2+}, \mathrm{Ca}^{2+}, \mathrm{Cl}^{-}, \mathrm{NO}_{3}{ }^{-}$and $\mathrm{SO}_{4}{ }^{2-}$.

been accounted for in the analyses. The median ratio of all samples is 1.17, indicating a cation excess that is present in $63 \%$ of the samples. In particular, high dust inputs as evidenced by increased concentrations of $\mathrm{Ca}^{2+}$ and $\mathrm{Mg}^{2+}$ are associated with a charge ratio much greater than 1 . Dust inputs probably include carbonate ions $\left(\mathrm{HCO}_{3}{ }^{-}\right.$and $\left.\mathrm{CO}_{3}{ }^{2-}\right)$ in concentrations large enough to balance the observed cation excesses (Toom-Sauntry and Barrie, 2002). The remaining $37 \%$ of the samples have an excess of anions that is presumably balanced by $\mathrm{H}^{+}$, which is generally the most abundant positive ion in water samples.

Correlation coefficients can be used to investigate interspecies relationships in our dataset. All correlations quoted are significant at $p=0.01$ for $n=320$. In our snow-pit samples, the sea-salt indicators $\mathrm{Na}^{+}$and $\mathrm{Cl}^{+}$are highly correlated $(r=0.93)$ while the dust indicators $\mathrm{Ca}^{2+}$ and $\mathrm{Mg}^{2+}$ are well correlated $(r=0.77) . \mathrm{K}^{+}$correlates best with $\mathrm{NH}_{4}{ }^{+}(r=0.52)$, implying a biomass-burning source, but is also correlated with $\mathrm{Ca}^{2+}(r=0.41)$ and $\mathrm{Mg}^{2+}(r=0.30)$, suggesting a contribution from crustal dust. Sulfate correlates best with $\mathrm{NH}_{4}{ }^{+}(r=0.73)$, suggesting these species are deposited in the same particles as ammonium sulfate. The stoichiometry suggests the form $\mathrm{NH}_{4} \mathrm{HSO}_{4}$ rather than $\left(\mathrm{NH}_{4}\right)_{2} \mathrm{SO}_{4}$ because the molar ratio of $\mathrm{NH}_{4}{ }^{+}$to $\mathrm{SO}_{4}{ }^{2-}$ averages 0.95 , very close to the $1: 1$ stoichiometry of $\mathrm{NH}_{4} \mathrm{HSO}_{4}$. Both $\mathrm{SO}_{4}{ }^{2-}(r=0.67)$ and $\mathrm{NO}_{3}{ }^{-}(r=0.66)$ correlate well with $\mathrm{Ca}^{2+}$, implying uptake of acidic species on dust particles. Alternatively, the correlation of $\mathrm{SO}_{4}{ }^{2-}$ with $\mathrm{Ca}^{2+}$ could suggest deposition of dust as gypsum $\left(\mathrm{CaSO}_{4}\right)$, but this does not explain the correlation of $\mathrm{NO}_{3}{ }^{-}$with $\mathrm{Ca}^{2+}$, nor are gypsum deposits, common only in internally draining basins, found in the North Pacific region in appreciable quantities.

\section{Sea-salt calculations}

Calculations of sea-salt and non-sea-salt fractions on a per sample basis indicate that nearly all of the $\mathrm{Ca}^{2+}(99 \%)$ and most of the $\mathrm{K}^{+}(86 \%)$ and $\mathrm{Mg}^{2+}(83 \%)$ at Eclipse are from non-sea-salt sources, presumably crustal dust but also including biomass burning in the case of $\mathrm{K}^{+}$. Sulfate is also mostly $(97 \%)$ from non-sea-salt sources, which include oxidation of sulfur dioxide from anthropogenic sources and 


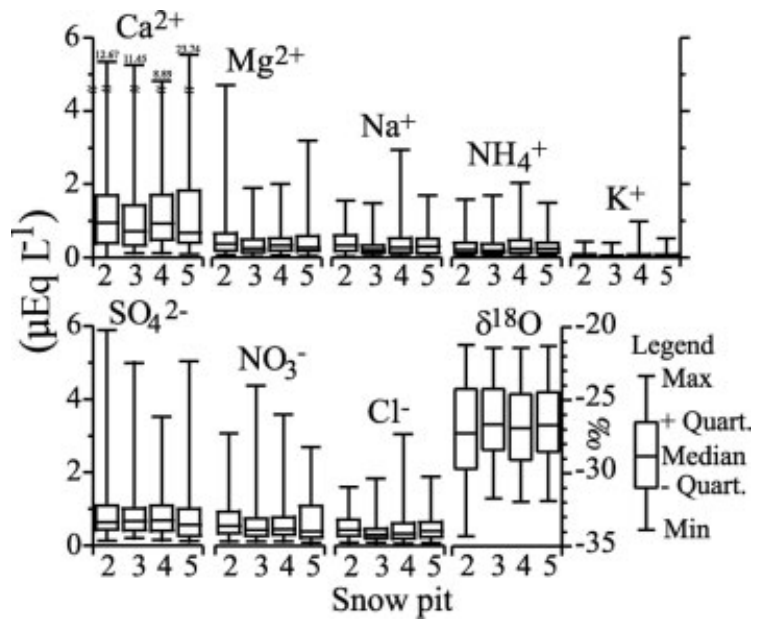

Fig. 4. Box plot summary of snow-pit chemical composition.

volcanic emissions, oxidation of dimethylsulfide produced by phytoplankton, and crustal dust and evaporate deposits. Although we assumed all of the $\mathrm{Na}^{+}$present is from sea salt, some of the $\mathrm{Na}^{+}$may be crustal in origin, particularly in dust-laden samples. Hence, the sea-salt and non-sea-salt fractions we calculated represent maximum and minimum estimates, respectively.

The $\mathrm{Cl}^{-}: \mathrm{Na}^{+}$micro-equivalent ratio in snow at Eclipse averages 1.26 , a $9 \%$ enrichment in $\mathrm{Cl}^{-}$relative to the seawater ratio of 1.16 (Keene and others, 1986). The $\mathrm{Cl}^{-}$ enrichment at Eclipse is considerably less than that observed at South Pole (40\%) or Summit, Greenland (23\%) (Whitlow and others, 1992). Excess chloride in polar snow may be derived from the reaction of sea-salt particles with acidic aerosols leading to release of gaseous $\mathrm{HCl}$ (Herron, 1982). Gas-phase $\mathrm{HCl}$ is highly soluble and readily scavenged by snowfall. Hence, chloride enrichment in snow may be interpreted as an indicator of long-range transport of marine aerosol, allowing greater volatilization of sea-salt chloride (Legrand and Delmas, 1988). Therefore, the proximity of Eclipse to sea-salt sources relative to Summit or South Pole may allow for less sea-salt acidification and volatilization of $\mathrm{HCl}$, resulting in less chloride enrichment at Eclipse and a $\mathrm{Cl}^{-}: \mathrm{Na}^{+}$ratio closer to that of sea water.

Calculations of sea-salt and non-sea-salt fractions do not change appreciably if an iterative approach is used to find the limiting sea-salt species instead of assuming that all of the $\mathrm{Na}^{+}$is from sea salt. The limiting sea-salt species is that species present in the lowest concentration relative to the sea-water ratio. Therefore the limiting species provides an estimate of the minimum sea-salt contribution, assuming no fractionation during production, transport and deposition of sea-salt aerosol (Keene and others, 1986). Sodium is found to be the limiting species in $99 \%$ of the samples. The limiting species in the remaining $1 \%$ of the samples is $\mathrm{K}^{+}, \mathrm{Mg}^{2+}$ or $\mathrm{Ca}^{2+}$, while $\mathrm{SO}_{4}{ }^{2-}$ is not found to be limiting in any of the samples. Again, nearly all of the $\mathrm{Ca}^{2+}(99 \%), \mathrm{K}^{+}(88 \%), \mathrm{Mg}^{2+}$ $(84 \%)$ and $\mathrm{SO}_{4}{ }^{2-}(95 \%)$ are found to be in excess of seawater ratios, while nearly all of the $\mathrm{Na}^{+}(92 \%)$ and $\mathrm{Cl}^{-}(85 \%)$ are present in sea-salt ratios. In contrast, up to $100 \%$ of the $\mathrm{Mg}^{2+}$ in Antarctica can be from sea salt (Whitlow and others, 1992). In such situations, determining the limiting sea-salt species on a per sample basis is necessary to determine whether $\mathrm{Na}^{+}$or $\mathrm{Mg}^{2+}$ provides the better sea-salt indicator.

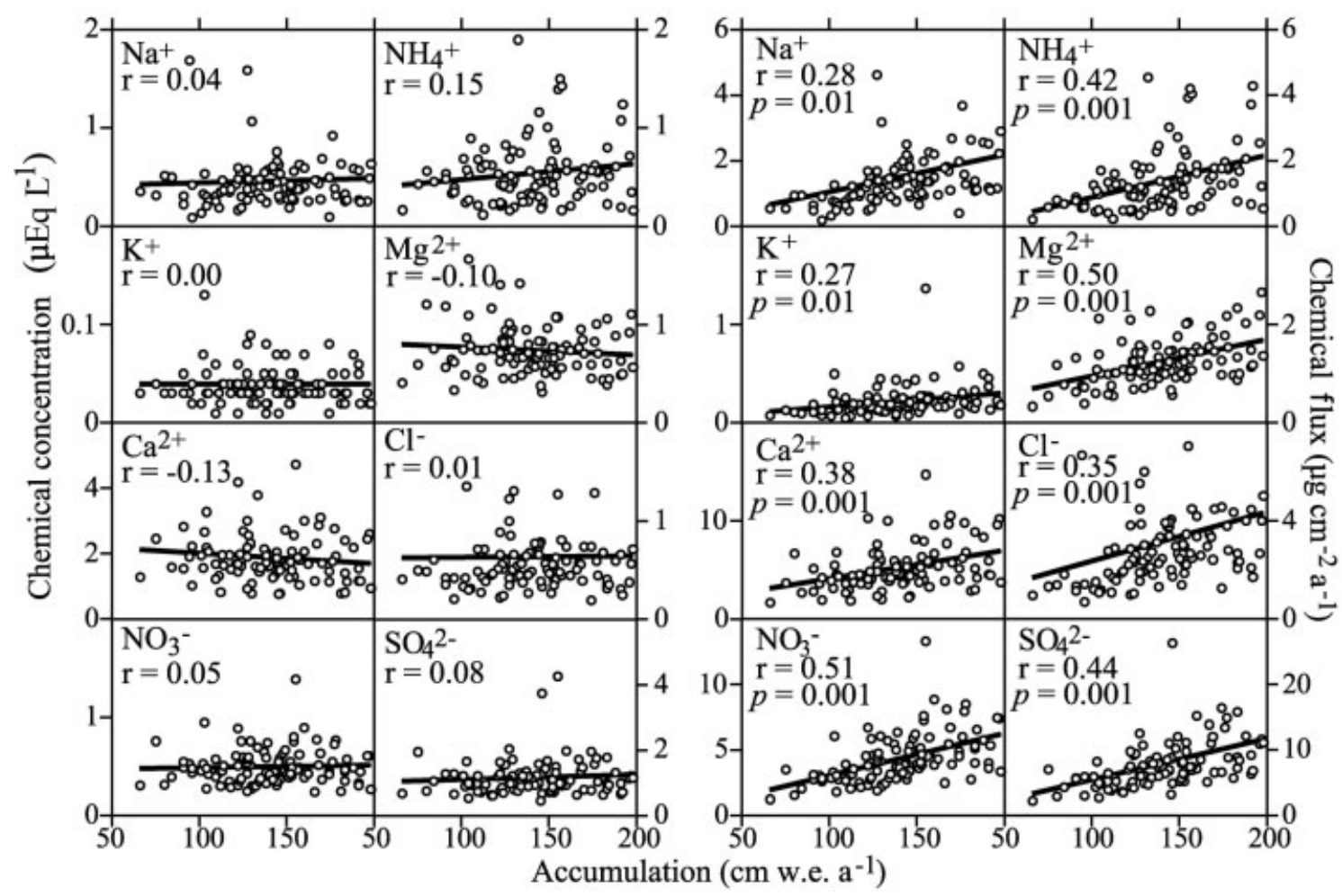

Fig. 5. Annual mean chemical concentration (left) and flux (right) vs snow accumulation for the Eclipse 1996 ice core. The solid line is the least-squares fitted regression line for each species, with correlation coefficients $(r)$ as indicated. For chemical concentration, none of these correlations are statistically significant at the $95 \%$ confidence level $(n=100)$. For chemical flux, statistical significance levels $(p)$ as indicated $(n=100)$. 


\section{Dependence on accumulation rate}

We used linear regression to investigate the relationship between the annually averaged concentration $\left(\mu \mathrm{Eq} \mathrm{L}^{-1}\right)$ of major ions and snow accumulation rate $\left(\mathrm{mw} . \mathrm{e} \cdot \mathrm{a}^{-1}\right)$ at Eclipse using the 100 year record provided by the Eclipse 1996 ice core. Results were similar using the Eclipse 2002 ice-core data. For all species, correlation coefficients are $<0.15$, indicating that snow accumulation rate is not an important control on the concentration of major ions at Eclipse (Fig. 5). Yang and others (1995) reached the same conclusion in their study of the GISP2 and 20D (Greenland) and Mount Logan ice-core datasets.

We also used linear regression to evaluate the dependence of chemical flux $\left(\mu \mathrm{g} \mathrm{cm}^{-2} \mathrm{a}^{-1}\right)$ on snow accumulation rate (Fig. 5). Positive relationships between chemical flux and snow accumulation are evident, with correlation coefficients ranging from 0.27 for $\mathrm{K}^{+}$to as high as 0.51 for $\mathrm{NO}_{3}{ }^{-}$. This indicates $7-26 \%$ of the variance in the flux data can be explained by a linear relationship with snow accumulation rate. Our results agree with those of Yang and others (1995) who report that the strongest correlation exists between nitrate flux and snow accumulation rate. Furthermore, our best-fit linear regression between nitrate flux and snow accumulation rate $(F=0.035 A-0.35$, where $F$ is nitrate flux in $\mu \mathrm{g} \mathrm{cm}^{-2} \mathrm{a}^{-1}$ and $A$ is the snow accumulation rate in $\mathrm{m}$ w.e. $\mathrm{a}^{-1}$ ) compares favorably to the relationship derived by Yang and others (1995) for Mount Logan $(F=0.054 A-0.19)$. We also find that $12-25 \%$ of the variance in the $\mathrm{NH}_{4}{ }^{+}, \mathrm{Mg}^{2+}, \mathrm{Ca}^{2+}, \mathrm{Cl}^{-}$and $\mathrm{SO}_{4}{ }^{2-}$ flux data is explained by a linear relationship with snow accumulation. Although no more than $20 \%$ of the flux variance of these species at GISP2 was explained by a linear relationship with snow accumulation rate, $36 \%$ of the variance in the Mount Logan sulfate flux data was explained (Yang and others, 1995). This may indicate a greater importance of wet deposition at high-accumulation-rate sites such as Eclipse, relative to the sites in the interior of ice sheets such as Greenland Ice Sheet Project 2 (GISP2) where dry and especially fog deposition can be an important contributor to chemical species flux (Bergin and others, 1995).

\section{Seasonal variations}

Comparison of individual species concentration profiles to the $\delta^{18} \mathrm{O}$ profile and to each other reveals distinct seasonal variations in all of the glaciochemical parameters measured, both in the snow-pit chemical profiles (Fig. 3) and in ice cores from Eclipse Icefield (Fig. 6). The most regular seasonal variations at Eclipse are seen in the $\delta^{18} \mathrm{O}$ record, which exhibits the classic signal of isotopically heavier (more negative) precipitation in winter and isotopically lighter (less negative) precipitation in summer (e.g. Dansgaard and others, 1973). Typical $\delta^{18} \mathrm{O}$ values for summer snowfall at Eclipse are $-24 \%$, with winter snowfall typically in the $-30 \%$ range. Summer-winter variations are also evident in the major-ion records and can be divided between sea-salt species $\left(\mathrm{Na}^{+}, \mathrm{Cl}^{-}\right)$that peak in late fall to winter and species associated with dust $\left(\mathrm{Ca}^{2+}, \mathrm{Mg}^{2+}\right)$ and other species $\left(\mathrm{NH}_{4}{ }^{+}\right.$, $\mathrm{NO}_{3}{ }^{-}, \mathrm{SO}_{4}{ }^{2-}$ ) that peak in late spring to summer.

Seasonal input timing of major-ion species at Eclipse is summarized in Figure 7 with respect to an idealized oxygen isotope curve. However, in any given year the relative timing of concentration peaks can differ markedly from the pattern

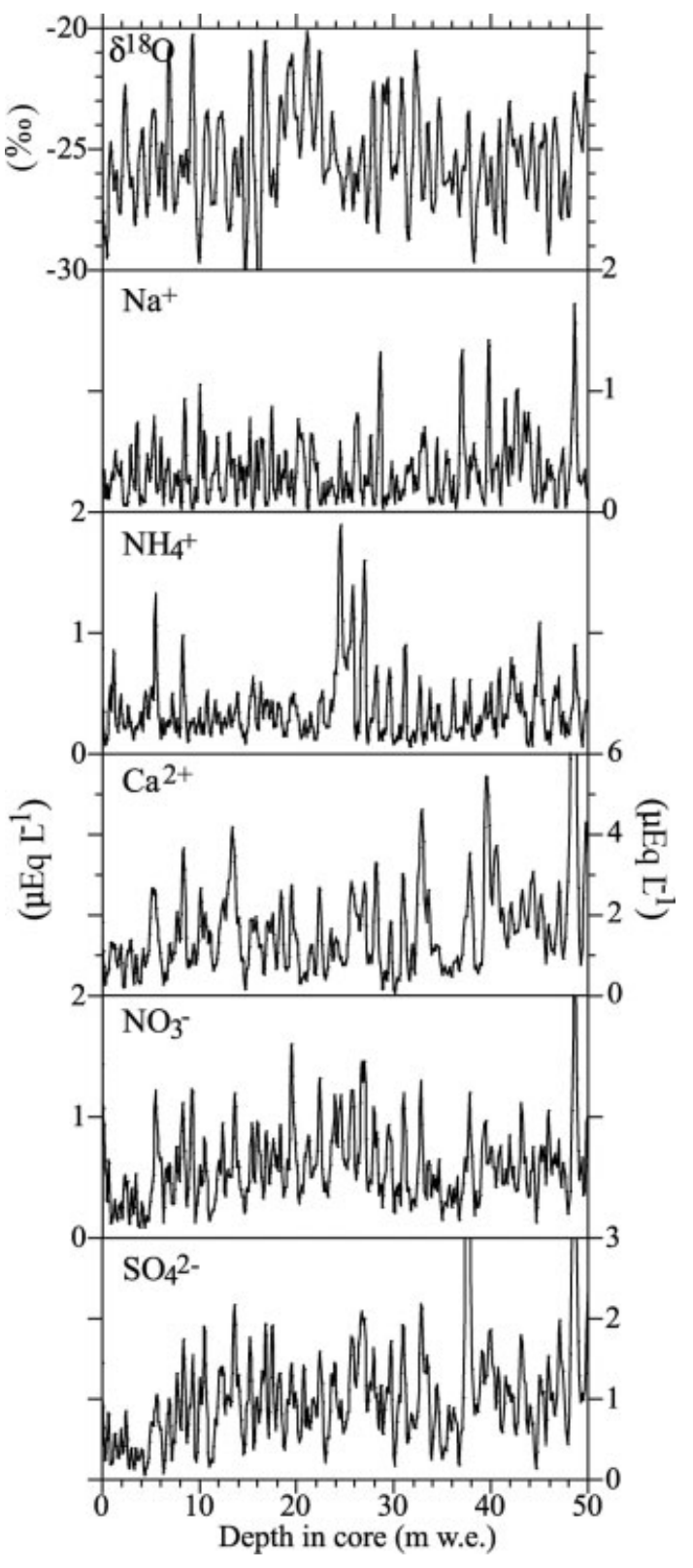

Fig. 6. The top $50 \mathrm{~m}$ of Eclipse core 3, covering the period 1963-2002. Note the strong seasonality of the signal not only in the $\delta^{18} \mathrm{O}$ profile, but also in the major-ion records. Because seasonality in $\mathrm{Cl}^{-}$deposition is highly correlated with $\mathrm{Na}^{+}(r=0.83)$ and $\mathrm{Mg}^{2+}$ is highly correlated with $\mathrm{Ca}^{2+}(r=0.87)$, neither $\mathrm{Cl}^{-}$nor $\mathrm{Mg}^{2+}$ is shown here.

described, especially for species influenced by episodic events, such as volcanic eruptions $\left(\mathrm{SO}_{4}{ }^{2-}\right)$ or forest fires $\left(\mathrm{NH}_{4}{ }^{+}\right)$. Concentrations of $\mathrm{Na}^{+}$and $\mathrm{Cl}^{-}$, derived mostly from sea salt, peak in late fall or winter either coincident with the $\delta^{18} \mathrm{O}$ minima or, less commonly, on the descending leg. This is presumably due to greater storminess in the nearby Gulf of Alaska during fall and winter, with higher wind speeds generating more wave action and enhanced entrainment of sea-salt aerosols, as well as more frequent advection of maritime air masses over Eclipse associated with greater inland penetration of stronger synoptic frontal systems (Taylor-Barge, 1969). Sea-salt concentrations are at their annual minima during summer.

Other species peak at Eclipse during spring or summer, with generally lower concentrations during winter. First to peak are those species indicative of dust, such as $\mathrm{Ca}^{2+}$ and 


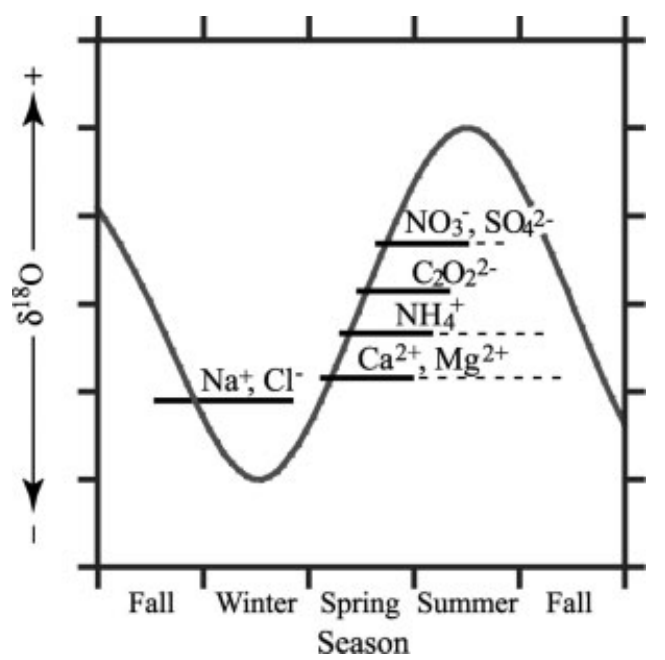

Fig. 7. Summary of chemical-species input timing at Eclipse with respect to an idealized oxygen isotope curve (after Whitlow and others, 1992). Solid lines indicate times when maximum concentrations frequently occur, while dashed extensions indicate periods when peaks are sometimes noted.

$\mathrm{Mg}^{2+}$ which most often peak on the rising leg of the $\delta^{18} \mathrm{O}$ curve, although their concentration maxima can extend throughout the summer. Slightly lagging the spring peak in crustal dust are the $\mathrm{NH}_{4}{ }^{+}$maxima, which also tend to peak on the rising leg of the $\delta^{18} \mathrm{O}$ curve. However, episodic biomass-burning events can overwhelm the seasonal $\mathrm{NH}_{4}{ }^{+}$ cycle and produce concentration maxima any time between spring and fall. Peak oxalate $\left(\mathrm{C}_{2} \mathrm{O}_{4}{ }^{2-}\right)$ concentrations tend to coincide with the spring-to-early-summer $\mathrm{NH}_{4}{ }^{+}$peak. The low $\mathrm{K}^{+}$concentrations make it difficult to infer any seasonality in $\mathrm{K}^{+}$deposition at Eclipse. However, $\mathrm{K}^{+}$concentration peaks often coincide with either $\mathrm{Ca}^{2+}$ or $\mathrm{Mg}^{2+}$ peaks, suggesting a $\mathrm{K}^{+}$source from crustal dust, or with $\mathrm{NH}_{4}{ }^{+}$ peaks, suggesting a biomass-burning source.

Sulfate and nitrate concentrations typically peak with the $\delta^{18} \mathrm{O}$ maxima, and hence slightly lag dust concentration peaks, although there is considerable overlap. Elevated $\mathrm{SO}_{4}{ }^{2-}$ and $\mathrm{NO}_{3}{ }^{-}$concentrations associated with dust inputs could suggest uptake of sulfate and nitrate by dust particles during atmospheric transport from continental source areas (as demonstrated by Jordan and others, 2003). The summer $\mathrm{NO}_{3}{ }^{-}$peak could be due to $\mathrm{NO}_{x}$ released by thermal decomposition of peroxyacetyl nitrate (PAN) in the presence of higher $\mathrm{OH}^{-}$concentrations in summer (Yang and others, 1995). Alternatively, the summer $\mathrm{NO}_{3}{ }^{-}$peak could indicate a summer peak in $\mathrm{NO}_{3}{ }^{-}$production by biological activity, biomass burning or lightning (Legrand and Kirchner, 1990). Holdsworth and Peake (1985) reported similar seasonal variations in nitrate in their analysis of snow pits and shallow firn cores from Eclipse. However, extensive postdepositional alteration of $\mathrm{NO}_{3}{ }^{-}$in snowpacks by photochemical recycling, and incomplete understanding of the underlying physical mechanisms responsible, complicates interpretation of glaciochemical $\mathrm{NO}_{3}{ }^{-}$records (Dibb and others, 2002).

Although the observed seasonality at Eclipse is similar to that at Summit, Greenland (Whitlow and others, 1992), distinct differences exist. Sodium concentrations at Summit tend to lag the $\delta^{18} \mathrm{O}$ minima and hence frequently overlap the spring dust concentration peak. This is thought to reflect under-representation of winter snow accumulation in the snowpack at Summit, allowing winter and spring concentration peaks separated in time by 3 months or more to overlap in the snowpack (Dibb, 1996). In contrast, the even distribution of snow accumulation throughout the year at Eclipse (with the exception of pit 3) preserves distinct seasalt maxima in winter and dust maxima in spring. Ammonium concentration peaks at Summit tend to occur in summer, coincident with the $\delta^{18} \mathrm{O}$ maxima, while at Eclipse they most often occur on the rising (spring) leg of the $\delta^{18} \mathrm{O}$ curve. $\mathrm{SO}_{4}{ }^{2-}$ concentrations tend to peak later at Eclipse in the vicinity of the $\delta^{18} \mathrm{O}$ maxima, while peak $\mathrm{SO}_{4}{ }^{2-}$ concentrations at Summit are a spring phenomenon. Relative input timings for dust species (spring) and $\mathrm{NO}_{3}{ }^{-}$ (summer) are the same at Eclipse and Summit.

\section{Spatial variations}

Box plots for each glaciochemical parameter measured in each individual snow pit provide a first-order perspective of the spatial variability at Eclipse (Fig. 4). Median values for oxygen isotopes are relatively constant for the four snow pits, although pit 2 displays a much greater range in oxygen isotope values. Oxygen isotope values at pit 3 are skewed towards less negative values, reflecting the relative lack of winter accumulation at that site. Not surprisingly, $\mathrm{Na}^{+}$and $\mathrm{Cl}^{-}$concentrations are lower at pit 3, since the time of maximum sea-salt concentrations (winter) is under-represented at that site. Median values for dust species $\left(\mathrm{Ca}^{2+}\right.$, $\mathrm{Mg}^{2+}$ ) are lower for pits 3 and 5, while $\mathrm{NH}_{4}{ }^{+}, \mathrm{NO}_{3}{ }^{-}$and $\mathrm{SO}_{4}{ }^{2-}$ have similar median values for all snow pits. For all species, the within-group variance, as indicated by the size of the box representing the variance of the samples about the median, is greater than the between-group variance as represented by the difference in median values between snow pits. This suggests that temporal or seasonal variability in snow chemistry is greater than the spatial variability.

We used empirical orthogonal function (EOF) analyses to further investigate the spatial variability between snow pits for each of the parameters measured (Table 2). The data from all four snow pits were pooled and a separate EOF decomposition was run for each of the species measured. Oxalate was excluded from this analysis because $56 \%$ of the snow-pit samples were below detection limits for this species. The EOF technique splits the temporal variance of a dataset into patterns termed empirical eigenvectors, which are orthogonal in nature (Peixoto and Oort, 1992). The first eigenvector explains the greatest percentage of variance in the dataset, with each successive eigenvector describing the maximum remaining variance. In this case, the first eigenvector describes the variance common to all four snow pits, since each snow pit has a positive correlation with the first EOF. The variance or signal common to all four snow pits identified by EOF 1 ranges from $49 \%$ of the total variance for $\mathrm{Na}^{+}$and $\mathrm{Cl}^{-}$to as high as $80 \%$ of the total variance for $\mathrm{SO}_{4}{ }^{2-}$.

Our results indicate that chemical species found in the accumulation mode $\left(\mathrm{NH}_{4}{ }^{+}, \mathrm{SO}_{4}{ }^{2-}\right)$ or gas phase $\left(\mathrm{NO}_{3}{ }^{-}\right)$ show less glaciochemical variability in snow pits at Eclipse than those species associated with coarse-mode dust $\left(\mathrm{Ca}^{2+}\right.$, $\mathrm{Mg}^{2+}$ ) or sea-salt $\left(\mathrm{Na}^{+}, \mathrm{Cl}^{-}\right.$) particles (Table 2). These results are consistent with studies of spatial variability in Greenland snow chemistry (e.g. Dibb and Jaffrezo, 1997). Sulfate and ammonium, presumably present primarily in the accumulation mode as $\mathrm{NH}_{4} \mathrm{HSO}_{4}$ aerosol (Seinfeld and Pandis, 
Table 2. Snow-pit per cent variance explained $\left(r^{2}\right)$ by EOF 1 . All loadings positive

\begin{tabular}{|c|c|c|c|c|c|c|c|c|c|}
\hline & $\delta^{18} \mathrm{O}$ & $\mathrm{Na}^{+}$ & $\mathrm{NH}_{4}{ }^{+}$ & $\mathrm{K}^{+}$ & $\mathrm{Mg}^{2+}$ & $\mathrm{Ca}^{2+}$ & $\mathrm{Cl}^{-}$ & $\mathrm{NO}_{3}^{-}$ & $\mathrm{SO}_{4}{ }^{2-}$ \\
\hline Pit 2 & 58.3 & 28.2 & 54.5 & 13.5 & 51.9 & 45.0 & 30.6 & 50.1 & 73.0 \\
\hline Pit 3 & 77.2 & 40.3 & 87.5 & 69.5 & 60.0 & 80.4 & 42.1 & 61.8 & 78.7 \\
\hline Pit 4 & 70.2 & 58.9 & 76.0 & 51.3 & 83.2 & 90.4 & 54.8 & 75.8 & 83.0 \\
\hline Pit 5 & 82.4 & 68.2 & 81.2 & 81.6 & 61.6 & 31.8 & 68.3 & 61.8 & 83.4 \\
\hline Total & 72.0 & 48.9 & 74.8 & 54.0 & 64.2 & 61.9 & 49.0 & 62.4 & 79.5 \\
\hline
\end{tabular}

1998), show the least variability in our snow pits, as evidenced by high EOF 1 loadings, with $55-83 \%$ of the signal common between snow pits. Nitrate, found mostly in the gas phase, has more variability at Eclipse than accumulation mode species $(50-76 \%$ of the signal common between snow pits), although less than species associated with coarse-mode dust or sea-salt particles. Uptake of nitrate by dust particles could result in an association of part of the snow nitrate with dust particles, increasing the spatial variability in nitrate concentrations. Species associated with sea salt $\left(\mathrm{Na}^{+}\right.$and $\left.\mathrm{Cl}^{-}\right)$and dust $\left(\mathrm{Ca}^{2+}, \mathrm{K}^{+}, \mathrm{Mg}^{2+}\right)$ particles display greater variability in our snow pits, as evidenced by lower EOF 1 loadings. The results obtained from the EOF analysis agree well with the box plots of Figure 4, which showed a greater range in median values for particleassociated species $\left(\mathrm{Na}^{+}, \mathrm{Cl}^{-}, \mathrm{Ca}^{2+}, \mathrm{Mg}^{2+}\right)$ than for species with gas-phase precursors $\left(\mathrm{NH}_{4}{ }^{+}, \mathrm{NO}_{3}{ }^{-}, \mathrm{SO}_{4}{ }^{2-}\right)$.

\section{CONCLUSIONS}

We have presented a glaciochemical survey of Eclipse Icefield using four $4 \mathrm{~m}$ snow pits, each representing approximately 1 year of accumulation, that were sampled for major ions and stable isotopes. Our discussion also incorporated results from the Eclipse ice cores to investigate controls on snow chemistry using a multi-year dataset, as our snow pits cover only 1 year's accumulation. The anomalously low accumulation since the end of the 2001 melt season at pit 3 (0.77 mw.e.) is due to underrepresentation of winter snowfall at this site, as indicated by snow-pit stratigraphy and chemical records. This could reflect enhanced wind erosion and removal of low-density winter snow at pit 3 via a funneling effect of the mountain slope to the east serving to focus wind energy. Calcium and sulfate are the dominant cation and anion in snow at Eclipse, respectively. Charge-balance calculations indicate a cation excess during high-dust periods that is presumably balanced by carbonate and/or bicarbonate ions. Linear regressions of annual chemical concentration vs snow accumulation rate for the 100 year Eclipse 1996 ice-core record demonstrate no relationship between individual species' annual mean concentration and snow accumulation rate. However, up to $26 \%$ of the variance in chemical flux can be explained by a linear dependence on snow accumulation rate. The relationship between flux and accumulation is strongest for $\mathrm{NO}_{3}{ }^{-}$, in agreement with previous studies (e.g. Yang and others, 1995).

Summer-winter variations are evident in the major-ion records and can broadly be divided between sea-salt species $\left(\mathrm{Na}^{+}, \mathrm{Cl}^{-}\right)$that peak in late fall to winter, and dust $\left(\mathrm{Ca}^{2+}, \mathrm{Mg}^{2+}, \mathrm{K}^{+}\right)$and other species $\left(\mathrm{NH}_{4}{ }^{+}, \mathrm{NO}_{3}{ }^{-}, \mathrm{SO}_{4}{ }^{2-}\right.$,
$\mathrm{C}_{2} \mathrm{O}_{2}{ }^{2-}$ ) that peak in late spring to summer. This understanding of seasonal input timing will aid interpretation of accumulation rate records from Eclipse Icefield ice cores by facilitating recognition of anomalously low-accumulation years that are due to a lack of preserved winter snowfall. Analysis of spatial variation in snow-pit chemistry suggests that species derived from coarse-mode sea-salt and dust particles $\left(\mathrm{Na}^{+}, \mathrm{Cl}^{-}, \mathrm{Ca}^{2+}, \mathrm{Mg}^{2+}, \mathrm{K}^{+}\right)$display more spatial variability in their glaciochemical concentrations than do species found primarily in the accumulation mode or gas phase $\left(\mathrm{NH}_{4}{ }^{+}, \mathrm{NO}_{3}{ }^{-}, \mathrm{SO}_{4}{ }^{2-}\right)$ due to the spotty nature of coarse-particle deposition, in agreement with the results of other studies (e.g. Dibb and Jaffrezo, 1997). Spatial variability in snow chemistry appears to be linked to the physical state of the species being deposited. The large amount of signal common to all four snow pits is encouraging for the use of ice cores from Eclipse Icefield in paleoclimatic reconstructions. Since sulfate has the highest amount of signal common to all four snow pits $(73-83 \%)$, our use of the Eclipse sulfate record in reconstructions of both anthropogenic sulfate deposition and the atmospheric effects of volcanic eruptions in the North Pacific is likely to yield particularly robust paleoclimatic reconstructions.

\section{ACKNOWLEDGEMENTS}

We thank E. Blake, S. Bastien and A. Mondrick for field assistance, and the Geological Survey of Canada (D. Fisher and C. Zdanowicz) for logistical support. We also thank E. Isaksson and P. Ginot for helpful and thorough reviews of the manuscript. The US National Science Foundation Office of Polar Programs funded this research.

\section{REFERENCES}

Bergin, M.H. and 8 others. 1995. The contributions of snow, fog, and dry deposition to the summer flux of anions and cations at Summit, Greenland. J. Geophys. Res., 100(D8), 16,275-16,288.

Dansgaard, W., S.J. Johnsen, H.B. Clausen and N. Gundestrup. 1973. Stable isotope glaciology. Medd. Grønl., 197(2), 1-53.

De Bell, L.J., M. Vozzella, R.W. Talbot and J.E. Dibb. 2004. Asian dust storm events of spring 2001 and associated pollutants observed in New England by the Atmospheric Investigation, Regional Modeling, Analysis and Prediction (AIRMAP) monitoring network. J. Geophys. Res., 109(D1), D01304. (10.1029/ 2003JD003733.)

Dibb, J.E. 1996. Overview of field data on the deposition of aerosol-associated species to the surface snow of polar glaciers, particularly recent work in Greenland. In Wolff, E.W. and R.C. Bales, eds. Chemical exchange between the atmosphere and polar snow. Berlin, etc., Springer-Verlag, 249-274. (NATO ASI Series I: Global Environmental Change 43.) 
Dibb, J.E. and J.L. Jaffrezo. 1997. Air-snow exchange investigations at Summit, Greenland: an overview. J. Geophys. Res., 102(C12), 26,795-26,807.

Dibb, J.E., M. Arsenault, M.C. Peterson and R.E. Honrath. 2002. Fast nitrogen oxide photochemistry in Summit, Greenland snow. Atmos. Environ., 36(15), 2501-2511.

Fisher, D.A., R.M. Koerner, W.S.B. Paterson, W. Dansgaard, N. Gundestrup and N. Reeh. 1983. Effect of wind scouring on climatic records from ice-core oxygen-isotope profiles. Nature, 301(5897), 205-209.

Goto-Azuma, K., R.M. Koerner, M. Nakawo and A. Kudo. 1997. Snow chemistry of Agassiz Ice Cap, Ellesmere Island, Northwest Territories, Canada. J. Glaciol., 43(144), 199-206.

Herron, M.M. 1982. Impurity sources of $\mathrm{F}^{-}, \mathrm{Cl}^{-}, \mathrm{NO}_{3}{ }^{-}$, and $\mathrm{SO}_{4}{ }^{2-}$ in Greenland and Antarctic precipitation. J. Geophys. Res., 87(C4), 3052-3060.

Holdsworth, G. and E. Peake. 1985. Acid content of snow from a mid-troposphere sampling site on Mount Logan, Yukon Territory, Canada. Ann. Glaciol., 7, 153-160.

Jordan, C.E., J.E. Dibb, B.E. Anderson and H.E. Fuelberg. 2003. Uptake of nitrate and sulfate on dust aerosols during TRACE-P. J. Geophys. Res., 108(D21), 8817. (10.1029/2002JD003101.)

Keene, W.C., A.A.P. Pszenny, J.N. Galloway and M.E. Hawley. 1986. Sea-salt corrections and interpretation of constituent ratios in marine precipitation. J. Geophys. Res., 91(D6), 6647-6658.

Kreutz, K.J. and 11 others. 1999. Seasonal variations of glaciochemical, isotopic and stratigraphic properties in Siple Dome (Antarctica) surface snow. Ann. Glaciol., 29, 38-44.

Kreutz, K.J., P.A. Mayewski, L.D. Meeker, M.S. Twickler and S.I. Whitlow. 2000. The effect of spatial and temporal accumulation rate variability in West Antarctica on soluble ion deposition. Geophys. Res. Lett., 27(16), 2517-2520.

Legrand, M.R. and R.J. Delmas. 1988. Formation of $\mathrm{HCl}$ in the Antarctic atmosphere. J. Geophys. Res., 93(D6), 7153-7168.

Legrand, M.R. and S. Kirchner. 1990. Origins and variations of nitrate in south polar precipitation. J. Geophys. Res., 95(D4), 3493-3507.

Legrand, M. and P. Mayewski. 1997. Glaciochemistry of polar ice cores: a review. Rev. Geophys., 35(3), 219-243.

Mayewski, P.A., M.J. Spencer, M.S. Twickler and S. Whitlow. 1990. A glaciochemical survey of the Summit region, Greenland. Ann. Glaciol., 14, 186-190.

Peixoto, J.P. and A.H. Oort. 1992. Physics of climate. New York, American Institute of Physics.
Seinfeld, J.H. and S.N. Pandis. 1998. Atmospheric chemistry and physics: from air pollution to climate change. New York, John Wiley and Sons.

Taylor-Barge, B. 1969. The summer climate of the St. Elias Mountains region. In Bushnell, V.C. and R.H. Ragle, eds. Icefield Ranges Research Project; scientific results. Montréal, Que., Arctic Institute of North America; New York, American Geographical Society, 33-49.

Toom-Sauntry, D. and L.A. Barrie. 2002. Chemical composition of snowfall in the high Arctic: 1990-1994. Atmos. Environ., 36(1516), 2683-2693.

Wake, C.P., K. Yalcin and N.S. Gundestrup. 2002. The climate signal recorded in the oxygen-isotope, accumulation and majorion time series from the Eclipse ice core, Yukon Territory, Canada. Ann. Glaciol., 35, 416-422.

Wake, C.P., P.A. Mayewski and S. Kang. 2004. Climatic interpretation of the gradient in glaciochemical signals across the crest of the Himalaya. In Cecil, L.D., J.R. Green and L.G. Thompson, eds. Earth paleoenvironments; records preserved in mid-and low-latitude glaciers. Volume 9. Boston, MA, Kluwer Academic Publishers, 81-94.

Whitlow, S., P.A. Mayewski and J.E. Dibb. 1992. A comparison of major chemical species seasonal concentration and accumulation at the South Pole and Summit, Greenland. Atmos. Environ., 26A(11), 2045-2054.

Yalcin, K. and C.P. Wake. 2001. Anthropogenic signals recorded in an ice core from Eclipse Icefield, Yukon, Canada. Geophys. Res. Lett., 28(23), 4487-4490.

Yalcin, K., C.P. Wake and M. Germani. 2003. A 100-year record of North Pacific volcanism in an ice core from Eclipse Icefield, Yukon Territory, Canada. J. Geophys. Res., 108(D1), 4012. (10.1029/2002JD00244.)

Yalcin, K., C.P. Wake, K.J. Kreutz and S.I. Whitlow. 2006. A 1000-yr record of forest fire activity from Eclipse Icefield, Yukon, Canada. The Holocene, 16(2), 200-209.

Yang, Q. and 7 others. 1995. A global perspective of nitrate flux in ice cores. J. Geophys. Res., 100(D3), 5113-5121.

Yang, Q., P.A. Mayewski, E. Linder, S. Whitlow and M. Twickler. 1996. Chemical species spatial distribution and relationship to elevation and snow accumulation rate over the Greenland ice sheet. J. Geophys. Res., 101(D13), 18,629-18,637.

Zdanowicz, C. and 7 others. 2004. Trans-Pacific transport of Asian desert dust: characterization of fallout in the St-Elias Mountains, Yukon, Canada. EOS Trans. AGU, 85(17). Joint Assembly Supplement, Abstract A23C-06. 